\title{
Pan-dent-emic: a dentist's dilemma in the COVID-19 era
}

\author{
Nidhi Manaktala ${ }^{1}$ (D), Swati Pralhad ${ }^{2}$ (D) and Roma $\mathrm{M}^{3^{*}}$ (D)
}

\begin{abstract}
The aftermath of the COVID-19 pandemic has been unfathomable. It has affected every sector within health care industry with dentistry being one of the worst hits. Not only has it impacted the dental practice, the field of dental education has been affected as well. There has been loss in terms of delayed to no treatments, finances, psychology and most importantly breaks in ongoing education and research practices. The present article attempts to explain the dilemma of the current situation from a dentist's perspective. Since, the effects of the contagion are seen across each level of dentistry, the current situation can truly be termed as a "Pan-dent-emic".
\end{abstract}

Keywords: Corona virus, COVID-19, Dentistry SARS- COV 2

The global pandemic spread by corona virus has apprehended the entire world and has created unprecedented concerns among health care personnel and general public alike. It has not only affected people's physical health, but also their mental health. Despite various efforts to prevent the pandemic spread, the flare-up of the disease is still mounting due to the community spread in every area. Additionally, the contagion has affected Dentistry not only in terms of practice management, but also at the most basic level of imparting dental education to students. While on one end of the spectrum, dental practice has been nearly stalled due to the fact that dental care professionals are at maximum risk of COVID-19 (SARS-CoV-2) infection, there also have been unforeseen changes in teaching practices and curriculum to make pedagogy more efficient in these times.

In an effort to combat COVID-19 infection, the world has conformed to the age-old Latin phrase "Aut inveniam viam aut faciam", wherein reformed practices have been instituted to provide dental care and education in these trying times. The standstill in dental practice

\footnotetext{
* Correspondence: roma.m@manipal.edu

${ }^{3}$ Department of Conservative Dentistry and Endodontics Manipal College of Dental Sciences, Manipal Academy of Higher Education, Karnataka 575001 Mangalore, India

Full list of author information is available at the end of the article
}

having led to delayed diagnoses and treatment has had many implications on patients. Nevertheless, dental practice management has striven endlessly to redeem itself using safety measures like tele-triages, screening of patients with questionnaires and digital thermometers; use of PPE (personal protective equipment) by dentist and auxiliaries and extensive sanitization during dental procedures [1]. The practice of tele-consultation, timebound appointments and following social distancing is already explained to patients before entering clinics so as to prevent overcrowding and cross contamination in clinical settings [2]. However, the psycho-economic setbacks incurred by the dental practitioner would take a long time to heal.

The education counterpart, however, has faced much indiscretion due to sudden changes in teaching practices. Recently, a term "covido-pedago-phobia" coined by Eachempati and Ramanaryan (2020) elucidated the quandary of timid 'digital immigrant' teachers who might experience mental paucity and reluctance while transitioning towards a more tech-savvy mode of teaching. They also discussed the impact of these modalities on students, the most important being the lack of social interaction leading to students becoming socially inept, which may undermine their ability to face challenges in 
the future [3]. Furthermore, in academic institutions, there has also been a simultaneous halt on research, biopsy and community services which has led to loss of time, finances along with an incumbent personal duress [4].

Overall, the COVID-19 crisis has led to an economic, psycho-social and physical impact, encompassing all aspects of dentistry. Hence, the present scenario can rightfully be termed as a "Pan-dent-emic". However, as they say, 'every cloud has a silver lining'; the advent of this pandemic has brought in a lot of positives as well. The dental community has never been more connected than present through webinars, online conferences and virtual continuing dental education programs [4]. There has also been a surge in medical/dental innovations wherein young researchers are working on applications to increase awareness via innovative digital mobile applications, creating devices to reduce and contain aerosols during dental procedures and much more [5]. The use of Whatsapp and other digital platforms in teaching, public health and reporting services have truly given rise to what we have always known as Tele-dentistry [6, 7].

On a general note, there has been a drastic decrease in respiratory illnesses with a natural cleansing of the environment [8]. Even when people are suffering from mental health issues, a study conducted by Barzilay (2020) indicated the signs of altruism in people's COVID-19 worries. They reported that increased resilience was paramount in reducing rates of anxiety and depression during the pandemic [9]. On a positive note, as and when the stabilization takes place, we as members of the oral health community must show resilience and ought to be grateful; and be cognizant that the old and the new normal must go hand in hand to truly bring back things to a state of equilibrium.

\section{Abbreviations}

SARS-CoV: Severe Acute Respiratory Syndrome Coronavirus; COVID-

19: Coronavirus disease

\section{Acknowledgements}

Not applicable.

\section{Authors' contributions}

RM was involved in preparation and editing of manuscript. RM, SP and NM were involved in literature search and refining of manuscript. The authors read and approved the final manuscript.

\section{Funding}

No funding sources.

\section{Availability of data and materials}

Data sharing is not applicable to this article as no datasets were generated or analyzed during the current study.

\section{Ethics approval and consent to participate}

Not applicable.

Consent for publication

Not applicable.

\section{Competing interests}

The authors of this case report declare that they have no competing interests.

\section{Author details}

${ }^{1}$ Department of Oral Pathology and Microbiology Manipal College of Dental Sciences, Manipal Academy of Higher Education, Karnataka 575001

Mangalore, India. ${ }^{2}$ Department of Periodontology, Manipal College of Dental Sciences, Manipal Academy of Higher Education, Karnataka 575001

Mangalore, India. ${ }^{3}$ Department of Conservative Dentistry and Endodontics

Manipal College of Dental Sciences, Manipal Academy of Higher Education, Karnataka 575001 Mangalore, India.

Received: 23 January 2021 Accepted: 31 January 2021

Published online: 14 February 2021

\section{References}

1. Patini R. How to face the post-SARS-CoV-2 outbreak era in private dental practice: current evidence for avoiding cross-infections. J Int Soc Prev Community Dent. 2020;10(3):237-9.

2. Ludovichetti FS, Signoriello AG, Stellini E, Mazzoleni S. COVID-19, rules of conduct for dental care in children during pandemic. Minerva Stomatol. 2020. https://doi.org/10.23736/50026-4970.20.04419-2. Epub ahead of print. PMID: 32744445

3. Eachempati P, Ramnarayan K. Covido-pedago-phobia. Med Educ. 2020;54(8): 678-80. https://doi.org/10.1111/medu.14257 Epub 2020 Jun 24. PMID: 32473029; PMCID: PMC7300974.

4. Wu DT, Wu KY, Nguyen TT, Tran SD. The impact of COVID-19 on dental education in North America-Where do we go next? Eur J Dent Educ. 2020. https://doi.org/10.1111/eje.12561. Epub ahead of print. PMID: 32654328; PMCID: PMC7404882.

5. Dente SMR, Hashimoto S. COVID-19: A pandemic with positive and negative outcomes on resource and waste flows and stocks. Resour Conserv Recycl. 2020;161:104979. https://doi.org/10.1016/j.resconrec.2020.104979 Epub 2020 Jun 2. PMID: 32536747; PMCID: PMC7264017.

6. Das R, Manaktala N, Bhatia T, Agarwal S, Natarajan S, Lewis AJ, Yellapurkar S. Efficiency of mobile video sharing application (WhatsApp ${ }^{\oplus}$ ) in live field image transmission for telepathology. J Med Syst. 2020;44(6):109. https://doi. org/10.1007/s10916-020-01567-W. PMID: 32361780; PMCID: PMC7196079.

7. Gueiros LA, Melo TS, Carrard VC. A simple tool to a complex realityWhatsApp use in a developing country during COVID-19 pandemic. Oral Dis. 2020.https://doi.org/10.1111/odi.13495. Epub ahead of print. PMID: 32558069.

8. Nelson B. The positive effects of covid-19. BMJ. 2020;369:m1785. https://doi. org/10.1136/bmj.m1785 PMID: 32366620.

9. Barzilay R, Moore TM, Greenberg DM, Di Domenico GE, Brown LA, White LK, Gur RC, Gur RE. Resilience COVID-19-related stress, anxiety and depression during the pandemic in a large population enriched for healthcare providers. Transl Psychiatry. 2020;10(1):291. https://doi.org/10.1038/s41398020-00982-4 PMID: 32820171; PMCID: PMC7439246.

\section{Publisher's Note}

Springer Nature remains neutral with regard to jurisdictional claims in published maps and institutional affiliations.

Ready to submit your research? Choose BMC and benefit from:

- fast, convenient online submission

- thorough peer review by experienced researchers in your field

- rapid publication on acceptance

- support for research data, including large and complex data types

- gold Open Access which fosters wider collaboration and increased citations

- maximum visibility for your research: over 100M website views per year

At BMC, research is always in progress.

Learn more biomedcentral.com/submissions 